\title{
Efficacy and Safety of Non-Vitamin K Antagonist Oral Anticoagulants in Patients with Atrial Fibrillation and Cancer in Real World: Meta-Analysis of Retrospective Observational Studies
}

\author{
Bo Cao ${ }^{1, \#}$, Xiaobo $\mathrm{Hu}^{1, \#}$, Min Chen ${ }^{2}$, Mingfeng Shen ${ }^{1, *}$, and Lan $\mathrm{Xu}^{1, *}$ \\ ${ }^{1}$ Department of Clinical Pharmacy, Affiliated Ninth Hospital of Suzhou University, Suzhou, China \\ ${ }^{2}$ Department of Cardiovascular Medicine, Affiliated Ninth Hospital of Suzhou University, Suzhou, China \\ "These authors contributed equally
}

\begin{abstract}
*Corresponding authors: Lan Xu, Department of Clinical Pharmacy, Affiliated Ninth Hospital of Suzhou University, Suzhou, China, E-mail: xulan848@126.com
\end{abstract}

Mingfeng Shen, Department of Clinical Pharmacy, Affiliated Ninth Hospital of Suzhou University, Suzhou, China, E-mail: 422644766@qq.com

Received: 30 May, 2021 | Accepted: 21 Jun, 2021 | Published: 7 Jul, 2021

Citation: Cao B, Hu X, Chen M, Shen M, Xu L (2021) Efficacy and Safety of Non-Vitamin K Antagonist Oral Anticoagulants in Patients with Atrial Fibrillation and Cancer in Real-World: Meta-Analysis of Retrospective Observational Studies. J Drug Res Dev 7(1): dx.doi.org/10.16966/24701009.162

Copyright: (C) 2021 Cao B, et al. This is an open-access article distributed under the terms of the Creative Commons Attribution License, which permits unrestricted use, distribution, and reproduction in any medium, provided the original author and source are credited.

\begin{abstract}
Background: Evidence on the safety and effectiveness of Non-Vitamin K Antagonist Oral Anticoagulants (NOACs) in Atrial Fibrillation (AF) patients with cancer is rather limited, so we performed this meta-analysis to compare the efficacy and safety of NOACs with vitamin K antagonists (VKAs) in real-world patients with AF and cancer.
\end{abstract}

Methods: The PubMed and Embase databases were searched up to June 2020 for eligible studies. Outputs were presented as Risk Ratios (RRs) and corresponding 95\% Confidence Intervals (Cls) using a random-effects model.

Results: A total of five observational studies involving 232, 234 cancer patients with AF were included. Compared with VKAs, use of NOACs was associated with decreased risks of stroke or systemic embolism (RR, $0.79 ; 95 \% \mathrm{Cl} 0.69-0.90)$, ischaemic stroke (RR, 0.82; 95\% $\mathrm{Cl}, 0.72-0.93)$, Venous Thromboembolism (VTE) (RR, 0.28; 95\% Cl 0.14-0.53), all-cause death (RR, 0.57; 95\% Cl 0.50-0.64), major bleeding (RR, 0.60; 95\% $\mathrm{Cl} 0.51-0.72)$ and intracranial or gastrointestinal bleeding $(\mathrm{RR}, 0.61 ; 95 \% \mathrm{Cl}, 0.51-0.73)$. In subgroup analysis, all NOACs showed similar rates of stroke or systemic embolism, ischaemic stroke but reduced rates of all-cause death, major bleeding and intracranial or gastrointestinal bleeding compared to VKAs.

Conclusions: In this combined analysis of real-world observational studies, NOACs showed lower risks of stroke or systemic embolism, ischaemic stroke, VTE, all-cause death and reduced rates of major bleeding and intracranial or gastrointestinal bleeding compared to VKAs in patients with AF and cancer.

Keywords: Atrial fibrillation; Cancer; Oral anticoagulants; Real-world; Meta-analysis

\section{Introduction}

Atrial Fibrillation (AF), inducing a five-fold increase in thromboembolic risk [1], is the most common cardiac arrhythmia. AF commonly occurs in cancer patients; approximately $2.5 \%$ with preexisting AF [2] and $30 \%$ will have new-onset $\mathrm{AF}$ [3]. The possible mechanism for higher prevalence of AF in cancer patients may be due to a hypercoagulable state $[4,5]$, anticancer drugs or chest surgery $[6,7]$. Cancer patients are at high risk of morbidity and mortality due to thrombosis and bleeding $[8,9]$. The risks of both thromboembolic and bleeding incidents are higher in AF patients with cancer compared to those free of cancer [10-14]. Therefore, the optimization of anticoagulation therapy is particularly important in reducing the risk of both thrombotic and bleeding complications in AF patients with cancer.
Warfarin is traditionally prescribed anticoagulant in prevention of thrombosis among AF patients. However, warfarin therapy remains challenging in $\mathrm{AF}$ patients with cancer because of the metabolic interactions with chemotherapy, chemotherapy-induced thrombocytopenia, and the frequent need for surgical or invasive procedures [15]. Non-vitamin K Antagonist Oral Anticoagulants (NOACs) are an alternative approach for stroke prevention in NonValvular AF (NVAF) patients. There are currently four NOACs available: factor Xa inhibitors (edoxaban, apixaban, and rivaroxaban) and direct thrombin inhibitor (dabigatran), which are considered as effective and safe as VKAs [16-18].

Although the efficacy and safety of NOACs in patients with venous thromboembolism and cancer has been well presented $[19,20]$, data of NOACs therapy in AF patients with cancer 
is extremely limited. There is no established guidance for anticoagulation management of AF patients with active cancer, and little controlled data on the use of NOACs of these population is found because the active cancer is usually an exclusion criterion in randomized NOAC trials $[21,22]$.

Therefore, data comparing the efficacy and safety of NOACs to VKAs is post hoc analysis of Randomized Clinical Trials (RCTs) [2325]. There were three meta-analyses assessing the performance of NOACs versus warfarin with the post hoc analysis data of RCTs and observational studies [26-28]. However, clinical trial populations are selected due to overly restrictive eligibility criteria and do not reflect all demographic features. Therefore, it's imperative to assess the efficacy and safety profiles of NOACs in real-world settings from observational studies. In this context, we performed an updated meta-analysis in observational studies of real-world representative populations to compare the efficacy and safety of NOACs with VKAs in NVAF patients with cancer.

\section{Methods}

The current analysis was performed according to the Meta-Analysis of Observational Studies in Epidemiology (MOOSE) [29]. There was no need to provide the ethical approval because all studies included for meta-analysis have been published already.

\section{Database and search}

We performed a systematic search in PubMed and Embase electronic database until June 2020 for relevant studies comparing the effect of any NOAC (apixaban, dabigatran, edoxaban or rivaroxaban) versus VKA in AF patients with cancer. The searching strategy was conducted by combining four kinds of search terms-1) "Atrial fibrillation" or "AF" and 2) "cancer" or "carcinoma" and 3) vitamin K antagonists or warfarin and 4) "new oral anticoagulants" or "non vitamin k antagonist oral anticoagulants" or "rivaroxaban" or "apixaban" or "edoxaban" or "dabigatran" or oral factor "Xa inhibitors" or "oral factor IIa inhibitors". We did not exclude any study due to linguistic restrictions and the references of retrieved studies were screened to identify additional reports which may have been neglected. The electronic search strategies are provided in Supplementary (Table S1).

\section{Selection and criteria}

Studies were considered to be eligible meeting the following criteria

1. Study design: observational studies.

2. Study population: AF patients with cancer.

3. Interventions: any NOAC (apixaban, dabigatran, edoxaban or rivaroxaban) compared to vitamin $\mathrm{K}$ antagonists or warfarin.

4. Outcomes: studies reported at least one of the efficacy or safety outcomes. Efficacy included Stroke or Systemic Embolism (SSE), Ischaemic Stroke (IS), Venous Thromboembolism (VTE) and all-cause death, and safety outcomes included major bleeding and intracranial or gastrointestinal bleeding.

The exclusion criteria were as follows

1) Articles such as systemic reviews, case reports and conference abstracts.

2) Clinical trials.

3) No data about endpoints and 4) absence of control groups.

\section{Efficacy and safety outcomes}

To assess the efficacy and safety of NOACs versus VKA, we included the following clinical outcomes:

1) Efficacy outcomes, including Stroke or Systemic Embolism (SSE), Ischaemic Stroke (IS), Venous Thromboembolism (VTE) [30] and all-cause death.

2) Safety outcomes, including major bleeding, according to the definition of original research (e.g., International Society on Thrombosis and Hemostasis criteria) [31], and intracranial or gastrointestinal bleeding.

\section{Data extraction and quality assessment}

All of the retrieved articles were assessed by two reviewers (Bo Cao and Xiaobo $\mathrm{Hu}$ ) independently. Titles and abstracts were screened for eligibility and then the full texts were reviewed in detail. The final selection of studies was performed by consensus. The extracted data included the first author's name, the year of publication, design, time period, patient characteristics, population size, treatment, control, type of cancer and follow-up duration. The Newcastle-Ottawa Scale (NOS) was used to assess the quality of the included observational studies, which includes three components: selection ( $0-4$ points), comparability ( $0-2$ points) and the assessment of the outcome (0-3 points). The specific information is presented in Supplementary (Table S2).

\section{Statistical analysis}

All of the statistical analyses were performed by using the Review Manager 5.3 software (the Nordic Cochrane Center, Rigshospitalet, Denmark) and Stata software (version 14.0, Stata Corp LP, College Station, TX). The Risk Ratio (RR) with 95\% Confidence Interval (CI) was calculated for each included study, and then pooled by a randomeffects model using the Mantel-Haenszel method. The Cochrane Q test and $\mathrm{I}^{2}$ statistic were the most commonly used statistical methods to evaluate heterogeneity, where $\mathrm{P}<0.1$ and $\mathrm{I}^{2}>50 \%$ indicated a substantial heterogeneity, respectively. In the sensitivity analysis, method of exclusion of one study at a time was used. We also performed the subgroup analysis based on the type of NOAC (apixaban, dabigatran or rivaroxaban). A value of $\mathrm{P}<0.05$ was considered statistically significant.

\section{Results \\ Description of included studies}

Database search generated 127 related articles and 5 studies [32-36] were identified for analysis after exclusion according to the eligibility criteria (Figure 1). All studies were retrospective and included a total of 232,234 patients, 44,739 were treated with NOACs and the remaining 187,495 with VKAs. The baseline characteristics of the included studies are shown in (Table 1). All included studies had an acceptable quality with an (NOS score $\geq 6$ ). Definitions of safety and efficacy endpoints in the 5 included studies were presented in Supplementary (Table S3).

\section{The efficacy of NOACs versus VKAs}

As presented in figure 2 and figure S1, the rates of stroke or systemic embolism were $10.7 \%$ in patients treated with NOACs versus $12.9 \%$ in those on VKAs, showing the decreased risk of SSE for NOACs users compared with VKAs (RR, 0.79; 95\% CI, 0.69-0.90; $\mathrm{I}^{2}=86 \%$ ). The incidence of ischaemic stroke was significantly different between NOACs and VKAs (10.1\% vs. $11.82 \%$; RR, 0.82; 95\% CI, 0.72-0.93; $\left.\mathrm{I}^{2}=85 \%\right)$. In two studies reporting venous thromboembolism, the use 


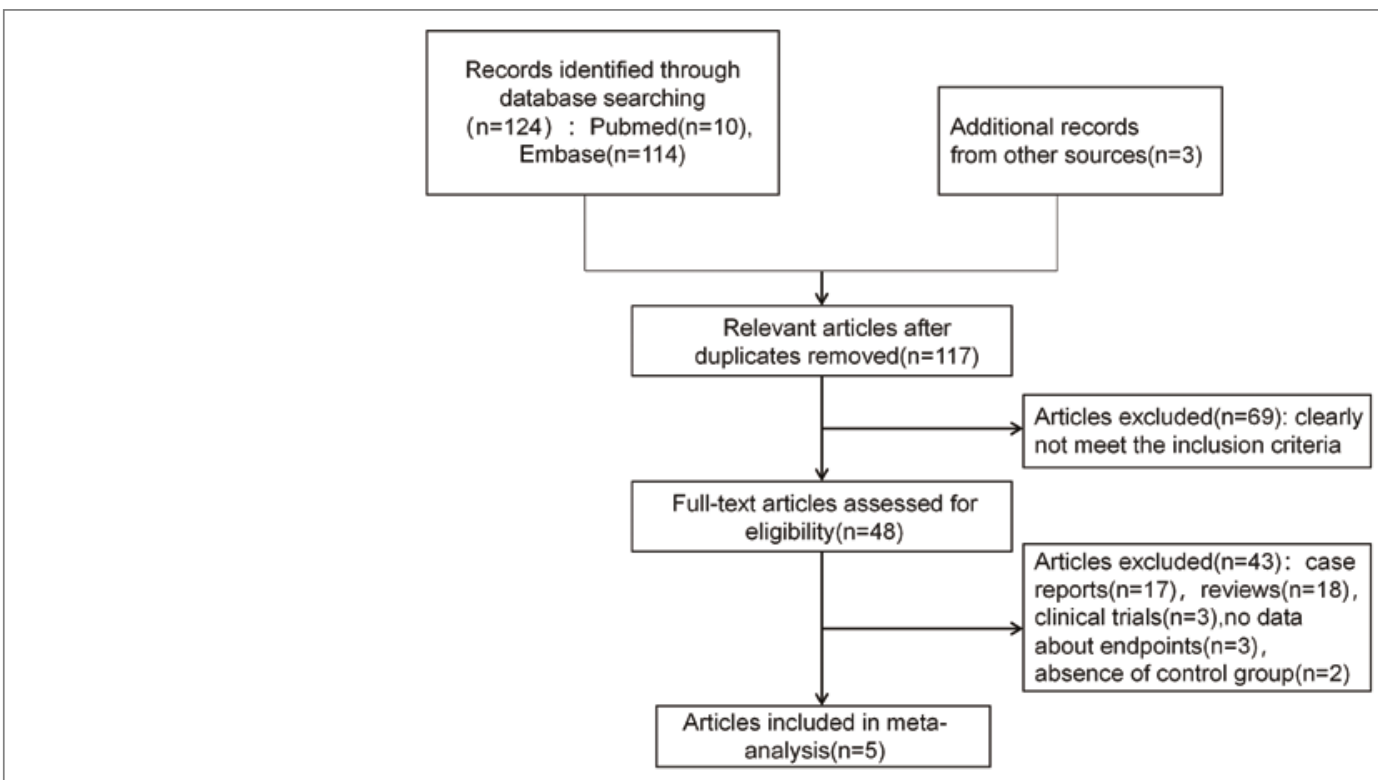

Figure 1: Flowchart diagram illustrating study selection methodology.

of NOACs was associated with reduced risk of VTE (2.4\% vs. $5.9 \%$, RR, 0.28; 95\% CI, 0.14-0.53; $\mathrm{I}^{2}=92 \%$ ) compared with VKAs. All-cause death was reported in two studies, and the incidence was significantly reduced in the NOACs group ( $25.9 \% v s .44 .8 \%$ in the VKAs group; RR, $0.57 ; 95 \%$ CI, $\left.0.50-0.64 ; \mathrm{I}^{2}=95 \%\right)$.

\section{The safety of NOACs versus VKAs}

Major bleeding was reported in all included studies as shown in figure 3 and figure $\mathrm{S} 1$, the rate of major bleeding was significant lower in people treated with NOACs compared to VKAs $(1.06 \%$ vs. $1.61 \%$, RR, $\left.0.60 ; 95 \% \mathrm{CI}, 0.51-0.72 ; \mathrm{I}^{2}=59 \%\right)$. Intracranial or gastrointestinal bleeding occurred in $1.0 \%$ of patients receiving NOACs and in $1.46 \%$ of those on VKAs (RR, $0.61 ; 95 \% \mathrm{CI}, 0.51-0.73 ; \mathrm{I}^{2}=59 \%$ ).

\section{Sensitivity analysis}

The sensitivity analysis was performed in analyzing the risk of stroke or systemic and major bleeding in NOACs versus VKAs, and the pooled effect results did not change when any individual included study was deleted at a time (Figure S2), which indicated reliable results.

\section{Subgroup analysis and publication bias}

The subgroup analysis was performed based on NOAC type, showing that apixaban, dabigatran or rivaroxaban had similar risks of SSE (Figure S3) or IS (Figure S4), but lower rates of all-cause death (Figure S5) compared with VKAs. In the safety outcome comparison of NOACs versus VKAs, all NOAC was associated with reduced risks of major bleeding (Figure S6) and intracranial or gastrointestinal bleeding (Figure S7) irrespective of NOAC type. It is difficult to evaluate publication bias with a funnel plot in analyses that include $<10$ studies, so we did not perform the publication bias analysis.

\section{Discussion}

In this meta-analysis of real-world observational studies, use of NOACs was associated with significant lower risks of stroke or systemic embolism, ischaemic stroke, VTE, all-cause death, major bleeding and intracranial or gastrointestinal bleeding compared to VKAs in AF patients with cancer. In subgroup analysis based on the type of NOACs, individual NOAC (apixaban, rivaroxaban or dabigatran) all showed similar rates of stroke or systemic embolism and ischaemic stroke, but lower rates of all-cause death, major bleeding and intracranial or gastrointestinal bleeding compared to VKAs.

The results are discordant from previous meta-analyses [26-28], which showed similar or lower rates of thromboembolic and bleeding events for NOACs users versus VKAs in AF patients with cancer. The results of Deng Y, et al. [28] showed the noninferior efficacy and safety of NOACs compared with VKAs but with wide confidence intervals and only borderline significant reductions in ischaemic stroke and major bleeding. Moreover, in Cavallari's meta-analysis [27], there were no significant reductions in thromboembolic events or major bleeding. Three studies of post hoc analysis of the NOAC seminal trials, i.e., ARISTOTLE [37], ROCKETAF [23], ENGAGE AF-TIMI48 [38] were all included and pooled separately [27] or together [26,28] with observational studies in these meta-analyses. However, participants in randomized clinical trials do not always represent the patients in real-world settings. Therefore, in our meta-analysis, only the realworld observational studies were included and we have extended the research period to June 2020, with much larger number of patients $(232,234)$ in real-life settings.

Compared with pooled analysis of three NOAC seminal trials [28], the rates of stroke or systemic embolism, ischaemic stroke, VTE and all-cause death were much higher while the risks of major bleeding and intracranial or gastrointestinal bleeding were much lower (Figure S1) in our combined analysis of real-world observational studies. The pooled analysis of three randomized trials showed similar risks of stroke/systemic embolism, ischaemic stroke, VTE and all-cause death with NOACs compared to VKAs, and only the rate of intracranial bleeding reduced in NOACs versus VKAs group [27]. However, in our analysis of real-world data, use of NOACs decreased the risks of all thromboembolic events compared to VKAs, as well as bleeding events. The difference could be explained by the more restricted clinical trial populations and the more controlled clinical environment in the followup daily practice in the clinical trials compared with real-life settings. However, observational studies always reflect more about practical use 
Table 1: Baseline characteristics of included studies.

\begin{tabular}{|c|c|c|c|c|c|c|c|c|c|c|c|}
\hline Study & Study design & Period & $\begin{array}{c}\text { Clinical } \\
\text { Characteristics }\end{array}$ & Population & $\begin{array}{c}\text { Age } \\
\text { (years) }\end{array}$ & $\begin{array}{c}\text { Female } \\
(\%)\end{array}$ & $\begin{array}{c}\text { ChA2DS2- } \\
\text { VASc }\end{array}$ & Treatment & Control & Type of cancer & $\begin{array}{l}\text { Follow- } \\
\text { up(years) }\end{array}$ \\
\hline $\begin{array}{l}\text { Ording } \\
\text { AG, et al. } \\
2017 \text { [33] }\end{array}$ & $\begin{array}{l}\text { Retrospective } \\
\text { cohort }\end{array}$ & $\begin{array}{l}07 / 2004- \\
12 / 2013\end{array}$ & AF, cancer & 11855 & 77 & 45.8 & 3.3 & NOAC & VKA & $\begin{array}{c}\text { Gastrointestinal } \\
(12.0 \%), \text { Cancer of } \\
\text { the lung or pleura } \\
\text { (3.9\%), Breast }(11.9 \%) \text {, } \\
\text { Urological }(14.5 \%) \\
\text { Intracranial }(0.1 \%), \\
\text { Hematological }(3.4 \%) \text {, } \\
\text { All other cancer sites } \\
(54.2 \%)\end{array}$ & 1 \\
\hline $\begin{array}{l}\text { Kim K, et } \\
\text { al. 2018 } \\
\text { [32] }\end{array}$ & $\begin{array}{c}\text { Retrospective } \\
\text { cohort }\end{array}$ & $\begin{array}{l}11 / 2005- \\
06 / 2015\end{array}$ & $\begin{array}{c}\text { non-valvular } \\
\text { AF, newly } \\
\text { diagnosed } \\
\text { cancer }\end{array}$ & 776 & 72.4 & 31.4 & 3.6 & $\begin{array}{c}\text { apixaban, } \\
\text { rivaroxaban, } \\
\text { dabigatran }\end{array}$ & warfarin & $\begin{array}{c}\text { Stomach }(20.6 \%) \text {, } \\
\text { colorectal }(14.9 \%) \text {, } \\
\text { thyroid }(10.8 \%) \text {, } \\
\text { prostate }(9.3 \%), \text { lung } \\
(12.2 \%), \\
\text { Melanoma (5.9\%), } \\
\text { biliary tract }(5.4 \%), \\
\text { urinary tract }(6.1 \%), \\
\text { genitourinary }(12.2 \%) \text {, } \\
\text { head and neck } \\
\text { (4.1\%), hepatocellular } \\
\text { carcinoma }(3.0 \%), \\
\text { breast (2.4\%), ovary } \\
\text { and endometrial }(2.6 \%), \\
\text { renal cell carcinoma } \\
\text { (3.1\%), hematologic } \\
\text { malignancy (2.2\%), } \\
\text { others (3.2\%) }\end{array}$ & 1.8 \\
\hline $\begin{array}{l}\text { Shah S, et } \\
\text { al. } 2018 \\
{[35]}\end{array}$ & $\begin{array}{l}\text { Retrospective } \\
\text { cohort }\end{array}$ & $\begin{array}{l}01 / 2010- \\
12 / 2014\end{array}$ & $\begin{array}{l}\text { non-valvular } \\
\text { AF, cancer }\end{array}$ & 22862 & 74.9 & 40 & 4.4 & $\begin{array}{c}\text { apixaban, } \\
\text { rivaroxaban, } \\
\text { dabigatran }\end{array}$ & warfarin & $\begin{array}{c}\text { Breast }(19.2 \%), \\
\text { gastrointestinal } \\
(12.7 \%) \text {, lung }(12.3 \%), \\
\text { genitourinary }(29.2 \%), \\
\text { gyneco- oncological } \\
(2.4 \%), \text { hematological } \\
(9.8 \%), \\
\text { Others }(14.4 \%)\end{array}$ & 1 \\
\hline $\begin{array}{l}\text { Yasui T, et } \\
\text { al. } 2019 \\
{[36]}\end{array}$ & $\begin{array}{l}\text { Retrospective } \\
\text { cohort }\end{array}$ & $\begin{array}{c}01 / 2014- \\
12 / 2016\end{array}$ & $\begin{array}{l}\text { AF, active } \\
\text { cancer }\end{array}$ & 224 & 72.7 & 12.5 & 3.1 & $\begin{array}{c}\text { apixaban, } \\
\text { rivaroxaban, } \\
\text { dabigatran }\end{array}$ & warfarin & $\begin{array}{c}\text { Gastrointestinal } \\
(44.2 \%), \text { Lung }(24.1 \%), \\
\text { Genitourinary }(11.2 \%), \\
\text { Head and neck }(9.8 \%), \\
\text { Breast }(4.0 \%), \\
\text { Hematological }(3.1 \%), \\
\text { Other }(3.6 \%)\end{array}$ & 1 \\
\hline $\begin{array}{l}\text { Sawant } \\
\text { AC, et al. } \\
2019 \\
{[32]}\end{array}$ & $\begin{array}{c}\text { Retrospective } \\
\text { cohort }\end{array}$ & $\begin{array}{l}01 / 2010- \\
12 / 2015\end{array}$ & $\begin{array}{l}\text { AF, active } \\
\text { cancer }\end{array}$ & 196517 & 76 & 1.9 & - & $\begin{array}{c}\text { apixaban, } \\
\text { rivaroxaban, } \\
\text { dabigatran }\end{array}$ & warfarin & - & - \\
\hline
\end{tabular}

of these drugs in clinical anticoagulation therapy. Actually, practical factors like cancer types, stages, antineoplastic drugs, comorbidities, patient preferences, potential drug-drug interactions all can affect real-world anticoagulation outcomes [39]. For example, pancreas, stomach, gynecological, brain, lung, hematological, and metastatic cancers are reported to have the higher propensity of thromboembolic risks $[40,41]$. In our analysis of included observational studies, proportion of these cancer types was obviously higher than that in three randomized trials (Table 1). Indeed, gastrointestinal malignancy was also associated with higher risk of gastrointestinal hemorrhages. The proportion of these patients, up to $44.2 \%$ in Yasui T, et al. study [36] and 20.6\% in Kim's study [32], was also much higher than that in three RCTs (average 8.5\%) [28]. Different from the similar results of NOACs versus VKAs regarding thromboembolic and bleeding events in RCTs [27], the incidences of both thromboembolic and bleeding events were significantly lower in our analysis, indicating a better efficacy and safety profile of NOACs compared to VKAs in AF patients with cancer in real-world settings.

In the aging population, the incidence and prevalence of $\mathrm{AF}$, VTE and cancer is increasing and evidence shows that there is higher risk of VTE and AF in cancer patients [42,43]. Indeed, thrombotic events are the second leading cause of mortality in patients with malignancy as approximately $20 \%$ of all VTE cases 


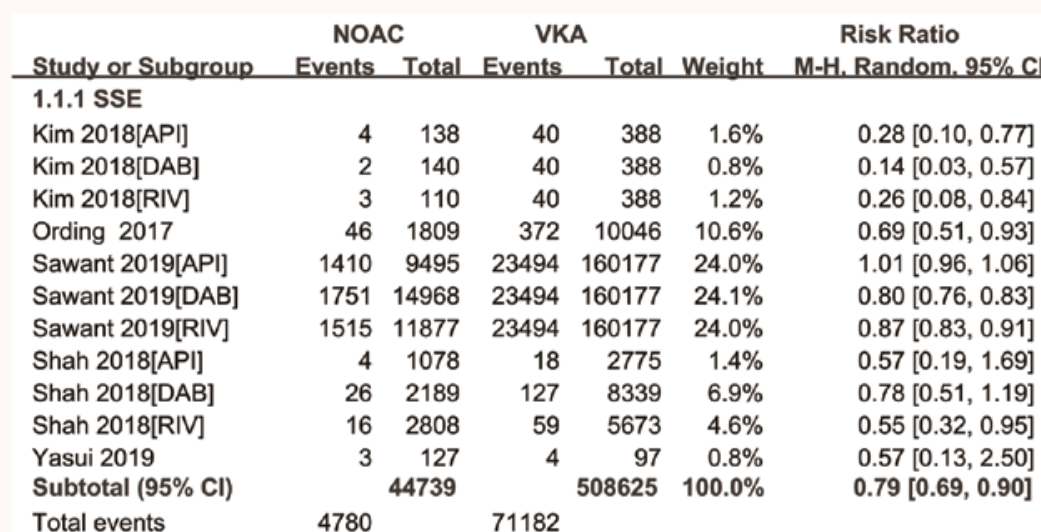

$\begin{array}{lcc}\text { Total events } & 4780 & 71182 \\ \text { Heterogeneity: } \text { Tau }^{2}=0.02 ; \mathrm{Chi}^{2}=71.53, \mathrm{df}=10 & (\mathrm{P}<0.00001) ; \mathrm{l}^{2}=86 \%\end{array}$

Test for overall effect: $Z=3.52(P=0.0004)$

\subsubsection{IS}

Kim 2018[API]

Kim 2018[DAB]

Kim 2018[RIV]

Ording 2017

Sawant 2019[API]

Sawant 2019[DAB]

Sawant 2019[RIV]

Shah 2018[API]

Shah 2018[DAB]

Shah 2018[RIV]

Yasui 2019

Subtotal $(95 \% \mathrm{Cl})$

Total events

Heterogeneity: Tau $^{2}=0.02 ; \mathrm{Chi}^{2}=65.65, \mathrm{df}=10(\mathrm{P}<0.00001) ; \mathrm{I}^{2}=85 \%$

Test for overall effect: $Z=3.01(P=0.003)$

\subsubsection{VTE}

Ording 2017

Shah 2018[API]

Shah 2018[DAB]

Shah 2018[RIV]

Subtotal $(95 \% \mathrm{Cl})$

Total events

Heterogeneity: $\mathrm{Tau}^{2}=0.39 ; \mathrm{Chi}^{2}=38.24, \mathrm{df}=3(\mathrm{P}<0.00001) ; \mathrm{I}^{2}=92 \%$

Test for overall effect: $Z=3.85(P=0.0001)$

\subsubsection{All-cause death}

Kim 2018[API]

Kim 2018[DAB]

Kim 2018[RIV]

Sawant 2019[API]

Sawant 2019[DAB]

Sawant 2019[RIV]

Subtotal $(95 \% \mathrm{CI})$

Total events

$\begin{array}{rr}12 & 1809 \\ 7 & 1078 \\ 49 & 2189\end{array}$

$2775 \quad 21.0 \%$

$743 \quad 8339 \quad 27.4 \%$

$\begin{array}{lllll}124 & 2808 & 472 & 5673 & 28.2 \%\end{array}$

$$
7884
$$

$\begin{array}{rrrrr}14 & 138 & 93 & 388 & 4.3 \% \\ 13 & 140 & 93 & 388 & 4.0 \% \\ 14 & 110 & 93 & 388 & 4.4 \% \\ 2849 & 9495 & 71920 & 160177 & 29.1 \% \\ 3742 & 14968 & 71920 & 160177 & 29.2 \% \\ 2898 & 11877 & 71920 & 160177 & 29.1 \% \\ 5 & 36728 & 481695 & 100.0 \%\end{array}$

$4.3 \%$
$0.29[0.10,0.79]$
$0.14[0.03,0.58]$
$0.27[0.09,0.86]$
$0.74[0.53,1.02]$
$1.04[0.99,1.09]$
$0.82[0.79,0.86]$
$0.89[0.85,0.94]$
$0.57[0.19,1.69]$
$0.78[0.51,1.19]$
$0.55[0.32,0.95]$
$1.15[0.20,6.72]$
$0.82[0.72,0.93]$

Heterogeneity: $\mathrm{Tau}^{2}=0.01 ; \mathrm{Chi}^{2}=106.13, \mathrm{df}=5(\mathrm{P}<0.00001) ; \mathbf{l}^{2}=95 \%$

Test for overall effect: $Z=9.45(P<0.00001)$ 


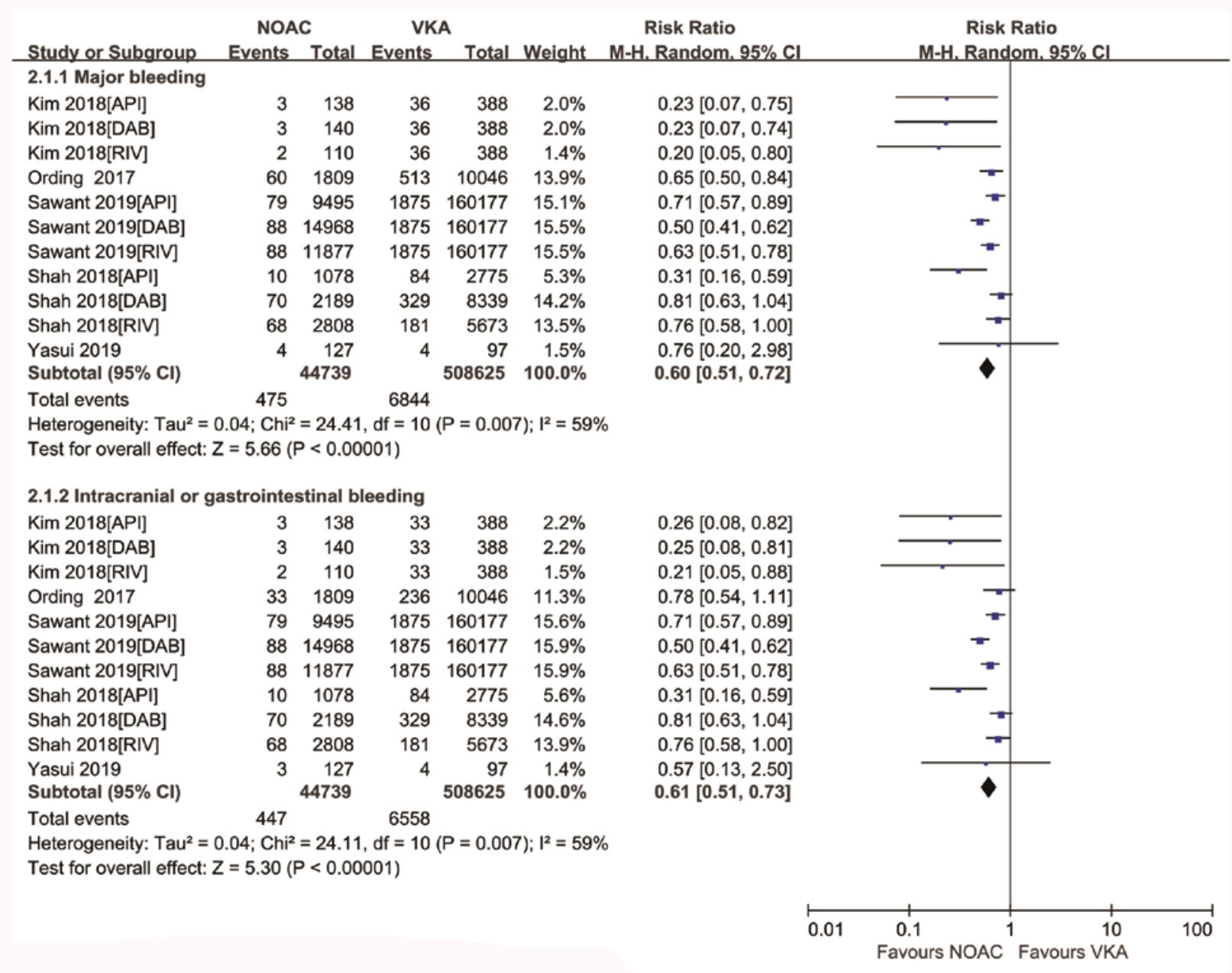

Figure 3: Forest plot comparing NOACs vs VKAs regarding the safety outcomes in real-world patients with AF and cancer. Atrial Fibrillation (AF); Non-Vitamin K Antagonist Oral Anticoagulants (NOACs); Vitamin K Antagonists (VKAs); Apixaban (API); Rivaroxaban (RIV); Dabigatran (DAB).

occur in patients with cancer [44,45]. Possible mechanism for higher prevalence of $\mathrm{AF}$ in cancer patients is autoimmune paraneoplastic syndrome, autonomic nervous dysfunction, systemic inflammation and a hypercoagulable state promoted by releasing fibrinolytic and procoagulant agents in this patient population [46]. Thus, the risk of thromboembolism in patients with $\mathrm{AF}$ and cancer would be higher and the optimized anticoagulant therapy should be explored. The SSC ISTH guidance from August 2019 recommends the use of NOACs over a VKA in patients on chemotherapy with newly diagnosed AF and individualized anticoagulation is recommended based wherever possible on the risk of stroke, bleeding, and patient values. However, the effect of NOACs might be interfered by the anticancer drugs in patients undergoing chemotherapy as these agents are inhibitors or inducers of P-glycoprotein or CYP3A4 [47]. Therefore, the drug-todrug interactions should be taken into consideration when NOACs are used in these patients.

We noticed that the statistical heterogeneity was significant across the included cohorts in some comparisons, however, the pooled results did not change in the sensitivity analysis, indicating that our results were reliable. Nevertheless, confouners do exist due to the nature of real-world data. First, the population across the included studies was heterogeneous, that two studies were Asians, two were Americans and one study was European patients. As have been reported, racial differences in baseline characteristics (e.g. age, body weight, comorbidities) may influence clinical outcomes [48]. Notably, Asian patients with AF have higher incidences of stroke and bleeding (especially intracranial bleeding) than non-Asians [48-50]. Moreover, reduced-dose NOACs therapy is common in Asia as many physicians have a tendency to prescribe a lower dose of NOACs to avoid bleeding complications [51]. Take dabigatran as an example, $88 \%$ patients were prescribed with $110 \mathrm{mg}$ and only $12 \%$ received $150 \mathrm{mg}$ in Asia [52]. As a result, the heterogeneous population and different regional anticoagulation therapy could lead to uncontrolled confounding. Despite the mainly same basic characteristics, patients in Sawant AC, et al. [34] were mainly males (98.1\%) as its population was selected from the veteran's affairs database and there's also low proportion of female (12.5\%) in Yasui T, et al. [36], which were different from three other cohorts with a mainly female proportion of $30 \%$ to $40 \%$. As female sex is an independent risk factor for AF-related stroke [53], and 
evidence shows that women are associated with an increased risk of thromboembolism $[54,55]$. Therefore, the extremely lower proportion of female in Sawant AC, et al. [34] and Yasui T, et al. [36] studies may lead to lower incidence of thromboembolism than in real world, which could result in the heterogeneity as well. Second, the type and dose of NOACs were different among these studies. The Danish cohort study [33] did not define which type of NOACs or VKAs was used, and patients in Kim k, et al. [32] study used both full and reduceddose of NOACs compared to warfarin. In addition, type of cancer and stage, the anticancer medication and type of chemotherapy drugs were also different across included studies, which may also count for the heterogeneity. Therefore, the effect of NOACs versus VKAs in AF and cancer should be further investigated for the optimal anticoagulation strategies taken the heterogeneity into consideration.

The subgroup analysis based on the NOAC type found that apixaban, rivaroxaban, or dabigatran had similar risks of stroke or systemic embolism, ischaemic stroke but reduced risks of all-cause death, major bleeding and intracranial or gastrointestinal bleeding compared with VKAs. However, it was notable that the risks of stroke or systemic embolism and ischaemic stroke were reduced when the data was pooled compared with VKAs. It might be explained by the limited number of studies, and even fewer studies analyzed in the subgroup analysis. Thus, further well-controlled large-scale studies would be needed to confirm the corresponding results. Overall, this meta-analysis of observational studies with more than 230,000 AF patients with cancer in real-world data showed better efficacy and safety profiles of NOACs compared to VKAs.

\section{Limitations}

Several limitations should be acknowledged in this meta-analysis. First, the heterogenicity of cancer, i.e., the cancer type, cancer staging and the chemotherapy drug, might result in bias. Second, the time in therapeutic range was not considered because only one included study [35] reported it in patients receiving VKAs. Third, residual confounders from unmeasured variables might exist due to the nature of real-world data. Fourth, two of the included cohorts had a relatively small number of study populations, which may limit the analytical power. Finally, the included observational studies were all retrospective, and high-quality prospective cohort's studies maybe required to confirm our findings.

\section{Conclusions}

Based on published real-world studies, NOACs showed lower risks of stroke or systemic embolism, ischaemic stroke, VTE, allcause death and reduced rates of major bleeding and intracranial or gastrointestinal bleeding compared to VKAs irrespective of NOAC type in patients with $\mathrm{AF}$ and cancer.

\section{Author Contributions}

Bo Cao and Xiaobo Hu contributed equally to this paper.

\section{Study concept and design}

Mingfeng Shen and Lan Xu.

Literature search, study selection and data extraction, quality assessment, and statistical analysis: Bo Cao and Xiaobo Hu.

\section{Drafting of the manuscript}

Bo Cao and Lan Xu.

\section{Manuscript revision}

Min Chen and Mingfeng Shen.

All authors approved the final version of the manuscript.

\section{Conflict of Interest}

The authors declare that they have no conflict of interest.

\section{Ethical Approval}

Not required.

\section{Funding/Support}

No external funding was available for this research.

\section{References}

1. Wang TJ, Massaro JM, Levy D, Vasan RS, Wolf PA, et al. (2003) A risk score for predicting stroke or death in individuals with new-onset atrial fibrillation in the community: the Framingham Heart Study. JAMA 290: 1049-1056.

2. Steffel J, Verhamme P, Potpara TS, Albaladejo P, Antz M, et al. (2018) The 2018 European Heart Rhythm Association Practical Guide on the use of non-vitamin $\mathrm{K}$ antagonist oral anticoagulants in patients with atrial fibrillation. Eur Heart J 39: 1330-1393.

3. O'Neal WT, Claxton JS, Sandesara PB, MacLehose RF, Chen LY, et al. (2018) Provider Specialty, Anticoagulation, and Stroke Risk in Patients With Atrial Fibrillation and Cancer. J Am Coll Cardiol 72: 1913-1922.

4. Neal WT, Lakoski SG, Qureshi W, Judd SE, Howard G, et al. (2015) Relation between cancer and atrial fibrillation (from the Reasons for Geographic And Racial Differences in Stroke Study) Am J Cardiol 115: 1090-1094.

5. Hu YF, Liu CJ, Chang PM, Tsao HM, Lin YJ, et al. (2013) Incident thromboembolism and heart failure associated with new-onset atrial fibrillation in cancer patients. Int J Cardiol 165: 355-357.

6. Nojiri T, Yamamoto K, Maeda H, Takeuchi Y, Funakoshi Y, et al. (2012) Effect of low-dose human atrial natriuretic peptide on postoperative atrial fibrillation in patients undergoing pulmonary resection for lung cancer: a double-blind, placebo-controlled study. J Thorac Cardiovasc Surg 143: 488-494.

7. Guzzetti S, Costantino G, Vernocchi A, Sada S, Fundarò C (2008) First diagnosis of colorectal or breast cancer and prevalence of atrial fibrillation. Intern Emerg Med 3: 227-231.

8. Timp JF, Braekkan SK, Versteeg HH, Cannegieter SC (2013) Epidemiology of cancer-associated venous thrombosis. Blood 112: 1712-1723.

9. Prandoni P, Lensing AW, Piccioli A, Bernardi E, Simioni P (2002) Recurrent venous thromboembolism and bleeding complications during anticoagulant treatment in patients with cancer and venous thrombosis. Blood 100: 3484-3488.

10. Chu G, Versteeg HH, Verschoor AJ, Trines SA, Hemels MEW, et al. (2019) Atrial fibrillation and cancer-An unexplored field in cardiovascular oncology. Blood Rev 35: 59-67.

11. Hu YF, Liu CJ, Chang PM, Tsao HM, Lin YJ, et al. (2013) Incident thromboembolism and heart failure associated with new-onset atrial fibrillation in cancer patients. Int J Cardiol 165: 355-357.

12. D'Souza M, Carlson N, Fosb $\varnothing \mid$ E, Lamberts M, Smedegaard L, et al. (2018) CHA 2 DS 2-VASc score and risk of thromboembolism and bleeding in patients with atrial fibrillation and recent cancer. Eur J Prev Cardiol 25: 651-658. 
13. Suter TM, Ewer MS (2013) Cancer drugs and the heart: importance and management. Eur Heart J 34: 1102-1111.

14. Farmakis D, Parissis J, Filippatos G (2014) Insights into oncocardiology: atrial fibrillation in cancer. J Am Coll Cardiol 63: 945-953.

15. Lee YJ, Park JK, Uhm JS, Kim JY, Pak HN, et al. (2016) Bleeding risk and major adverse events in patients with cancer on oral anticoagulation therapy. Int J Cardiol 203: 372-378.

16. Ruff CT, Giugliano RP, Braunwald E, Hoffman EB, Deenadayalu N, et al. (2014) Comparison of the efficacy and safety of new oral anticoagulants with warfarin in patients with atrial fibrillation: a meta-analysis of randomised trials. Lancet 383: 955-962.

17. Kirchhof P, Benussi S, Kotecha D, Ahlsson A, Atar D, et al. (2016) 2016 ESC Guidelines for the management of atrial fibrillation developed in collaboration with EACTS. Eur Heart J 37: 2893-2962.

18. Dentali F, Riva N, Crowther M, Turpie AG, Lip GY, et al. (2012) Efficacy and safety of the novel oral anticoagulants in atrial fibrillation: a systematic review and meta-analysis of the literature. Circulation 126: 2381-2391.

19. Raskob GE, van Es N, Verhamme P, Carrier M, Di Nisio M, et al. (2018) Edoxaban for the Treatment of Cancer-Associated Venous Thromboembolism. N Engl J Med 378: 615-624.

20. Vedovati MC, Germini F, Agnelli G, Becattini C (2015) Direct oral anticoagulants in patients with VTE and cancer: a systematic review and meta-analysis. Chest 147: 475-483.

21. Connolly SJ, Ezekowitz MD, Yusuf S, Eikelboom J, Oldgren J, et al. (2009) Dabigatran versus warfarin in patients with atrial fibrillation. N Engl J Med 361: 1139-1151.

22. Natale A, Mohanty S, Gianni C (2017) Comparison of different oral anticoagulant regimens in patients with atrial fibrillation: is the risk of left atrial appendage thrombus formation truly comparable between regimens? Pol Arch Intern Med 127: 810-812.

23. Chen ST, Hellkamp AS, Becker RC, Berkowitz SD, Breithardt G, et al. (2019) Efficacy and safety of rivaroxaban vs. warfarin in patients with non-valvular atrial fibrillation and a history of cancer: observations from ROCKET AF. Eur Heart J Qual Care Clin Outcomes 5: 145-152.

24. Fanola CL, Ruff CT, Murphy SA, Jin J, Duggal A, et al. (2018) Efficacy and Safety of Edoxaban in Patients With Active Malignancy and Atrial Fibrillation: Analysis of the ENGAGE AF-TIMI 48 Trial. J Am Heart Assoc 7: e008987.

25. Melloni C, Dunning A, Granger CB, Thomas L, Khouri MG, et al. (2017) Efficacy and Safety of Apixaban versus Warfarin in Patients with Atrial Fibrillation and a History of Cancer: Insights from the ARISTOTLE Trial. Am J Med 130: 1440-1448.

26. Yang P, Zhu D, Xu X, Shen W, Wang C, et al. (2019) Efficacy and safety of oral anticoagulants in atrial fibrillation patients with cancer-a network meta-analysis. Heart Fail Rev 25: 823-831.

27. Cavallari I, Verolino G, Romano S, Patti G (2020) Efficacy and Safety of Nonvitamin K Oral Anticoagulants in Patients with Atrial Fibrillation and Cancer: A Study-Level Meta-Analysis. Thromb Haemost 120 : 314-321.

28. Deng $Y$, Tong $Y$, Deng $Y$, Zou L, Li S, et al. (2019) Non-Vitamin K Antagonist Oral Anticoagulants Versus Warfarin in Patients With Cancer and Atrial Fibrillation: A Systematic Review and MetaAnalysis. J Am Heart Assoc 8: e012540.

29. Stroup DF, Berlin JA, Morton SC, Olkin I, Williamson GD, et al. (2000) Meta-analysis of observational studies in epidemiology: a proposal for reporting. Meta-analysis Of Observational Studies in Epidemiology (MOOSE) group. JAMA 283: 2008-2012.
30. Kearon C, Akl EA, Ornelas J, Blaivas A, Jimenez D, et al. (2016) Antithrombotic Therapy for VTE Disease: CHEST Guideline and Expert Panel Report. Chest 149: 315-352.

31. Lip GY, Andreotti F, Fauchier L, Huber K, Hylek E, et al. (2011) Bleeding risk assessment and management in atrial fibrillation patients: a position document from the European Heart Rhythm Association, endorsed by the European Society of Cardiology Working Group on Thrombosis. Europace 13: 723-246.

32. Kim K, Lee YJ, Kim TH, Uhm JS, Pak HN, et al. (2018) Effect of Nonvitamin $\mathrm{K}$ Antagonist Oral Anticoagulants in Atrial Fibrillation Patients with Newly Diagnosed Cancer. Korean Circ J 48: 406-417.

33. Ording AG, Horváth-Puhó $E$, Adelborg K, Pedersen L, Prandoni $P$, et al. (2017) Thromboembolic and bleeding complications during oral anticoagulation therapy in cancer patients with atrial fibrillation: a Danish nationwide population-based cohort study. Cancer Med 6: 1165-1172.

34. Sawant AC, Kumar A, Mccray W, Tetewsky S, Parone L, et al. (2019) Superior safety of direct oral anticoagulants compared to Warfarin in patients with atrial fibrillation and underlying cancer: a national veterans affairs database study. J Geriatr Cardiol 16: 706-709.

35. Shah S, Norby FL, Datta YH, Lutsey PL, MacLehose RF, et al. (2018) Comparative effectiveness of direct oral anticoagulants and warfarin in patients with cancer and atrial fibrillation. Blood Adv 2: 200-209.

36. Yasui T, Shioyama W, Oboshi M, Oka T, Fujita M (2019) Oral Anticoagulants in Japanese Patients with Atrial Fibrillation and Active Cancer. Intern Med 58: 1845-1849.

37. Melloni C, Dunning A, Granger CB, Thomas L, Khouri MG, et al. (2017) Efficacy and Safety of Apixaban versus Warfarin in Patients with Atrial Fibrillation and a History of Cancer: Insights from the ARISTOTLE Trial. Am J Med 130: 1440-1448.

38. Fanola CL, Ruff CT, Murphy SA, Jin J, Duggal A, et al. (2018) Efficacy and Safety of Edoxaban in Patients With Active Malignancy and Atria Fibrillation: Analysis of the ENGAGE AF - TIMI 48 Trial. 21: e008987.

39. Undas A, Drabik L (2020) Non-vitamin K antagonist oral anticoagulants (NOACs) in cancer patients with atrial fibrillation. Anatol J Cardiol 23: 10-18.

40. Walker AJ, Card TR, West J, Crooks C, Grainge MJ (2013) Incidence of venous thromboembolism in patients with cancer - a cohort study using linked United Kingdom databases. Eur J Cancer 49: 1404-1413.

41. Horsted F, West J, Grainge MJ (2012) Risk of venous thromboembolism in patients with cancer: a systematic review and meta-analysis. PLoS Med 9: e1001275.

42. Benjamin EJ, Blaha MJ, Chiuve SE, Cushman M, Das SR, et al. (2017) Heart Disease and Stroke Statistics-2017 Update: A Report From the American Heart Association. Circulation 135: e146-e603.

43. Farmakis D, Parissis J, Filippatos G (2014) Insights into oncocardiology: atrial fibrillation in cancer. J Am Coll Cardiol 63: 945-953.

44. Khorana AA, Francis CW, Culakova E, Kuderer NM, Lyman GH (2007) Thromboembolism is a leading cause of death in cancer patients receiving outpatient chemotherapy. J Thromb Haemost 5: 632-634.

45. Prandoni P, Lensing AW, Piccioli A, Bernardi E, Simioni P, et al. (2002) Recurrent venous thromboembolism and bleeding complications during anticoagulant treatment in patients with cancer and venous thrombosis. Blood 100: 3484-3488.

46. Mery B, Guichard JB, Guy JB, Vallard A, Barthelemy JC, et al. (2017) Atrial fibrillation in cancer patients: Hindsight, insight and foresight. Int J Cardiol 240: 196-202.

Citation: Cao B, Hu X, Chen M, Shen M, Xu L (2021) Efficacy and Safety of Non-Vitamin K Antagonist Oral Anticoagulants in Patients with Atrial Fibrillation and Cancer in Real-World: Meta-Analysis of Retrospective Observational Studies. J Drug Res Dev 7(1): dx.doi.org/10.16966/2470- 
47. Wessler JD, Grip LT, Mendell J, Giugliano RP (2013) The P-glycoprotein transport system and cardiovascular drugs. J Am Coll Cardiol 61 2495-2502.

48. Wong KS, Hu DY, Oomman A, Tan RS, Patel MR, et al. (2014) Rivaroxaban for stroke prevention in East Asian patients from the ROCKET AF trial. Stroke 45: 1739-1747.

49. Goto S, Zhu J, Liu L, Oh BH, Wojdyla DM, et al. (2014) Efficacy and safety of apixaban compared with warfarin for stroke prevention in patients with atrial fibrillation from East Asia: a subanalysis of the Apixaban for Reduction in Stroke and Other Thromboembolic Events in Atrial Fibrillation (ARISTOTLE) Trial. Am Heart J 168: 303-309.

50. Shen AY, Yao JF, Brar SS, Jorgensen MB, Chen W (2007) Racial/ethnic differences in the risk of intracranial hemorrhage among patients with atrial fibrillation. J Am Coll Cardiol 50: 309-315.

51. Sato T, Aizawa Y, Fuse K, Fujita S, Ikeda Y, et al. (2018) The Comparison of Inappropriate-Low-Doses Use among 4 Direct Oral Anticoagulants in Patients with Atrial Fibrillation: From the Database of a SingleCenter Registry. J Stroke Cerebrovasc Dis 27: 3280-3288.
52. Chan YH, Yen KC, See LC, Chang SH, Wu LS, et al. (2016) Cardiovascular, Bleeding, and Mortality Risks of Dabigatran in Asians With Nonvalvular Atrial Fibrillation. Stroke 47: 441-449.

53. Bushnell C, McCullough LD, Awad IA, Chireau MV, Fedder WN, et al. (45) Guidelines for the prevention of stroke in women: a statement for healthcare professionals from the American Heart Association/ American Stroke Association. Stroke 45: 1545-1588.

54. Friberg L, Benson L, Rosenqvist M, Lip GY (2012) Assessment of female sex as a risk factor in atrial fibrillation in Sweden: nationwide retrospective cohort study. BMJ 344: e3522.

55. Fang MC, Singer DE, Chang Y, Hylek EM, Henault LE, et al. (2005) Gender differences in the risk of ischemic stroke and peripheral embolism in atrial fibrillation: the Anticoagulation and Risk factors In Atrial fibrillation (ATRIA) study. Circulation 112: 1687-1691.

\section{Supplementary Information:}

Table S1: Electronic search strategies determined on June, 2020.

\begin{tabular}{|c|c|}
\hline Databases & Queries \\
\hline \multicolumn{2}{|r|}{ PubMed } \\
\hline \#1 & Atrial fibrillation [MeSH Terms] OR AF [Title/Abstract] \\
\hline \#2 & Cancer [MeSH Terms] OR carcinoma [Title/Abstract] \\
\hline \#3 & $\begin{array}{c}\text { new oral anticoagulants [Title/Abstract] OR non-vitamin K antagonist oral } \\
\text { anticoagulants [Title/Abstract] OR rivaroxaban [Title/Abstract] OR apixaban [Title/Abstract] OR edoxaban [Title/Abstract] OR oral } \\
\text { factor Xa inhibitors [Title/Abstract] } \\
\text { OR dabigatran [Title/Abstract] OR oral factor } \mathbb{I} \text { a inhibitors [Title/Abstract] }\end{array}$ \\
\hline \#4 & Warfarin [MeSH Terms] OR vitamin K antagonists [Title/Abstract] \\
\hline \#5 & $\# 1$ and \#2 and \#3 and \#4 \\
\hline \multicolumn{2}{|r|}{ EMBASE } \\
\hline$\# 1$ & 'Atrial fibrillation': ab, ti OR 'AF': ab, ti \\
\hline \#2 & 'cancer': ab, ti OR 'carcinoma': ab, ti \\
\hline \#3 & $\begin{array}{l}\text { 'new oral anticoagulants': ab, ti OR 'non-vitamin k antagonist oral anticoagulants': ab, ti OR rivaroxaban: ab, ti OR apixaban: ab, ti } \\
\text { OR edoxaban: ab, ti OR 'oral factor Xa inhibitors': ab, ti OR dabigatran: ab, ti OR 'oral factor ii a inhibitors': ab, ti }\end{array}$ \\
\hline \#4 & 'warfarin': ab, ti OR 'vitamin K antagonists': ab, ti \\
\hline \#5 & $\# 1$ and \#2and \#3 and \#4 \\
\hline
\end{tabular}

Citation: Cao B, Hu X, Chen M, Shen M, Xu L (2021) Efficacy and Safety of Non-Vitamin K Antagonist Oral Anticoagulants in Patients with Atrial Fibrillation and Cancer in Real-World: Meta-Analysis of Retrospective Observational Studies. J Drug Res Dev 7(1): dx.doi.org/10.16966/2470- 
Table S2: NOS for assessment of quality of included studies.

\begin{tabular}{|c|c|c|c|c|c|c|c|c|c|c|}
\hline \multirow[b]{2}{*}{$\begin{array}{l}\text { Included } \\
\text { studies }\end{array}$} & \multicolumn{4}{|c|}{ Selection (0-4 points) } & \multicolumn{2}{|c|}{$\begin{array}{c}\text { Comparability (0-2 } \\
\text { points) }\end{array}$} & \multicolumn{3}{|c|}{ Outcome (0-3 points) } & \multirow[b]{2}{*}{$\begin{array}{c}\text { Total } \\
\text { points }\end{array}$} \\
\hline & $\begin{array}{c}\text { Representativeness } \\
\text { of Exposed Cohort }\end{array}$ & $\begin{array}{c}\text { Selectionn } \\
\text { of Non- } \\
\text { Exposed } \\
\text { Cohort }\end{array}$ & $\begin{array}{c}\text { Ascertainment } \\
\text { of Exposure }\end{array}$ & $\begin{array}{l}\text { Demonstration } \\
\text { That Outcome } \\
\text { of Interest Was } \\
\text { Not Present at } \\
\text { Start of Study }\end{array}$ & $\begin{array}{c}\text { Adjust } \\
\text { for the } \\
\text { important } \\
\text { Risk factors }\end{array}$ & $\begin{array}{c}\text { Adjust for } \\
\text { other risk } \\
\text { factors }\end{array}$ & $\begin{array}{c}\text { Assessment } \\
\text { of } \\
\text { outcome }\end{array}$ & $\begin{array}{c}\text { Follow- } \\
\text { up } \\
\text { length }\end{array}$ & $\begin{array}{l}\text { Loss to } \\
\text { follow- } \\
\text { up rate }\end{array}$ & \\
\hline $\begin{array}{l}\text { Kim K, et al. } \\
2018 \text { [32] }\end{array}$ & $*$ & $*$ & $*$ & & $*$ & $*$ & $*$ & $*$ & $*$ & 8 \\
\hline $\begin{array}{l}\text { Ording AG, et } \\
\text { al. } 2017 \text { [33] }\end{array}$ & $*$ & $*$ & $*$ & & $*$ & $*$ & $*$ & $*$ & $*$ & 8 \\
\hline $\begin{array}{l}\text { Sawant AC, et } \\
\text { al. } 2019 \text { [34] }\end{array}$ & $*$ & $*$ & $*$ & & $*$ & $*$ & $*$ & & & 6 \\
\hline $\begin{array}{l}\text { Shah S, et al. } \\
2018 \text { [35] }\end{array}$ & $*$ & $*$ & $*$ & & * & $*$ & $*$ & $*$ & $*$ & 8 \\
\hline $\begin{array}{l}\text { Yasui T, et al. } \\
2019 \text { [36] }\end{array}$ & $*$ & $*$ & $*$ & $*$ & $*$ & $*$ & $*$ & $*$ & $*$ & 9 \\
\hline
\end{tabular}

The Newcastle-Ottawa Scale (NOS) items, with a total score of 9 points, were used to evaluate the quality of the observational studies, which involve the selection of cohorts (0-4 points), the comparability of cohorts (0-2 points), and the assessment of the outcome (0-3 points).

Table S3: Definitions of safety and efficacy endpoints in the 5 included studies.

\begin{tabular}{|c|c|c|c|c|c|c|}
\hline References & $\begin{array}{l}\text { Stroke or systemic } \\
\text { embolism }\end{array}$ & Ischaemic stroke & VTE & All-cause death & Major bleeding & $\begin{array}{c}\text { Intracranial or } \\
\text { gastrointestinal bleeding }\end{array}$ \\
\hline $\begin{array}{l}\text { Kim K, et al. } \\
2018 \text { [32] }\end{array}$ & $\begin{array}{l}\text { Ischaemic stroke } \\
\text { or systemic } \\
\text { thromboembolism }\end{array}$ & Ischaemic stroke & NA & All-cause death & ISTH & $\begin{array}{l}\text { Intracranial or } \\
\text { gastrointestinal bleeding }\end{array}$ \\
\hline $\begin{array}{l}\text { Ording AG, et } \\
\text { al. } 2017 \text { [33] }\end{array}$ & $\begin{array}{l}\text { Ischaemic stroke, } \\
\text { hemorrhagic stroke, } \\
\text { other arterial } \\
\text { embolism }\end{array}$ & Ischaemic stroke & VTE & NA & $\begin{array}{l}\text { hemorrhagic stroke } \\
\text { or gastrointestinal, } \\
\text { lung, or urinary } \\
\text { hemorrhage }\end{array}$ & $\begin{array}{l}\text { hemorrhagic stroke or } \\
\text { gastrointestinal hemorrhage }\end{array}$ \\
\hline $\begin{array}{l}\text { Sawant AC, et } \\
\text { al. } 2019 \text { [34] }\end{array}$ & Ischaemic stroke & Ischaemic stroke & NA & $\begin{array}{l}\text { All-cause } \\
\text { mortality }\end{array}$ & hemorrhagic stroke & hemorrhagic stroke \\
\hline $\begin{array}{l}\text { Shah S, et al. } \\
2018 \text { [35] }\end{array}$ & Ischaemic stroke & Ischaemic stroke & $\begin{array}{l}\text { Venous } \\
\text { thromboembolism }\end{array}$ & NA & $\begin{array}{l}\text { Intracranial } \\
\text { hemorrhage or } \\
\text { gastrointestinal } \\
\text { bleeding }\end{array}$ & $\begin{array}{l}\text { Intracranial hemorrhage or } \\
\text { gastrointestinal bleeding }\end{array}$ \\
\hline $\begin{array}{l}\text { Yasui T, et al. } \\
2019[36]\end{array}$ & $\begin{array}{l}\text { Stroke or systemic } \\
\text { embolism }\end{array}$ & Ischaemic stroke & NA & NA & ISTH & $\begin{array}{c}\text { Intracranial or } \\
\text { gastrointestinal bleeding }\end{array}$ \\
\hline
\end{tabular}

Abbreviations: VTE: Venous Thromboembolism; ISTH: International Society on Thrombosis and Haemostasis; NA: Not Available 


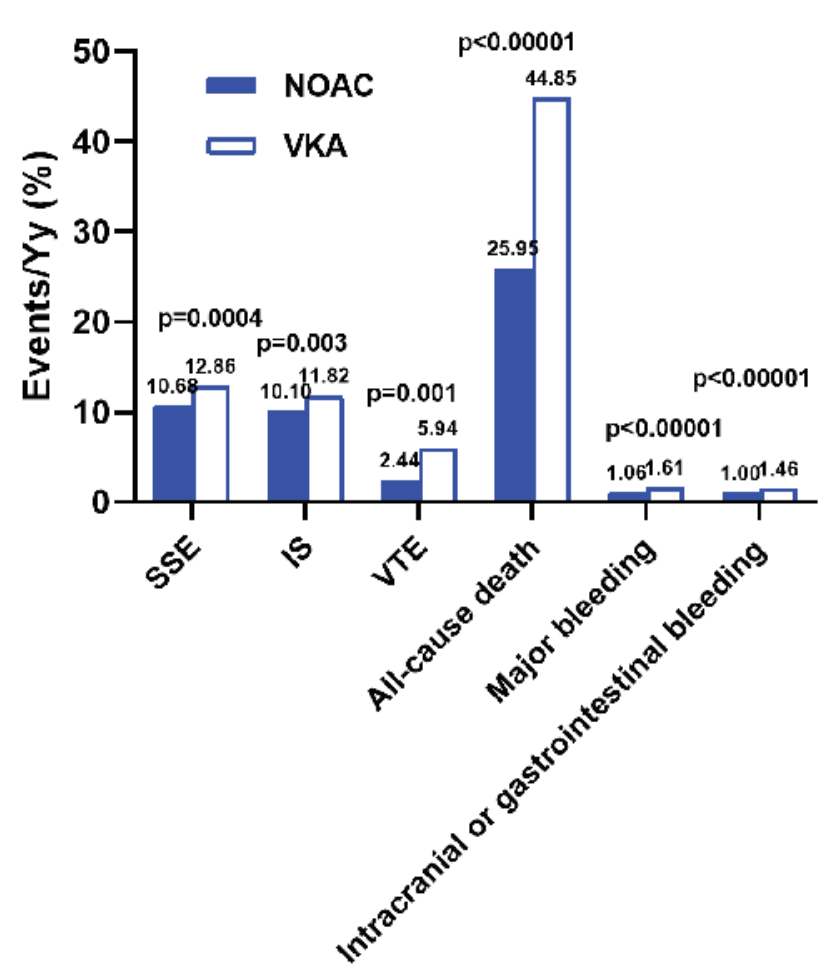

Figure S1: Incidence rates of clinical events in real-world AF patients with cancer receiving NOACs vs VKAs. Atrial Fibrillation (AF); Stroke or Systemic Embolism (SSE); Ischaemic Stroke (IS); Venous Thromboembolism (VTE); Non-Vitamin K Antagonist Oral Anticoagulants (NOACs); Vitamin K Antagonists (VKAs)

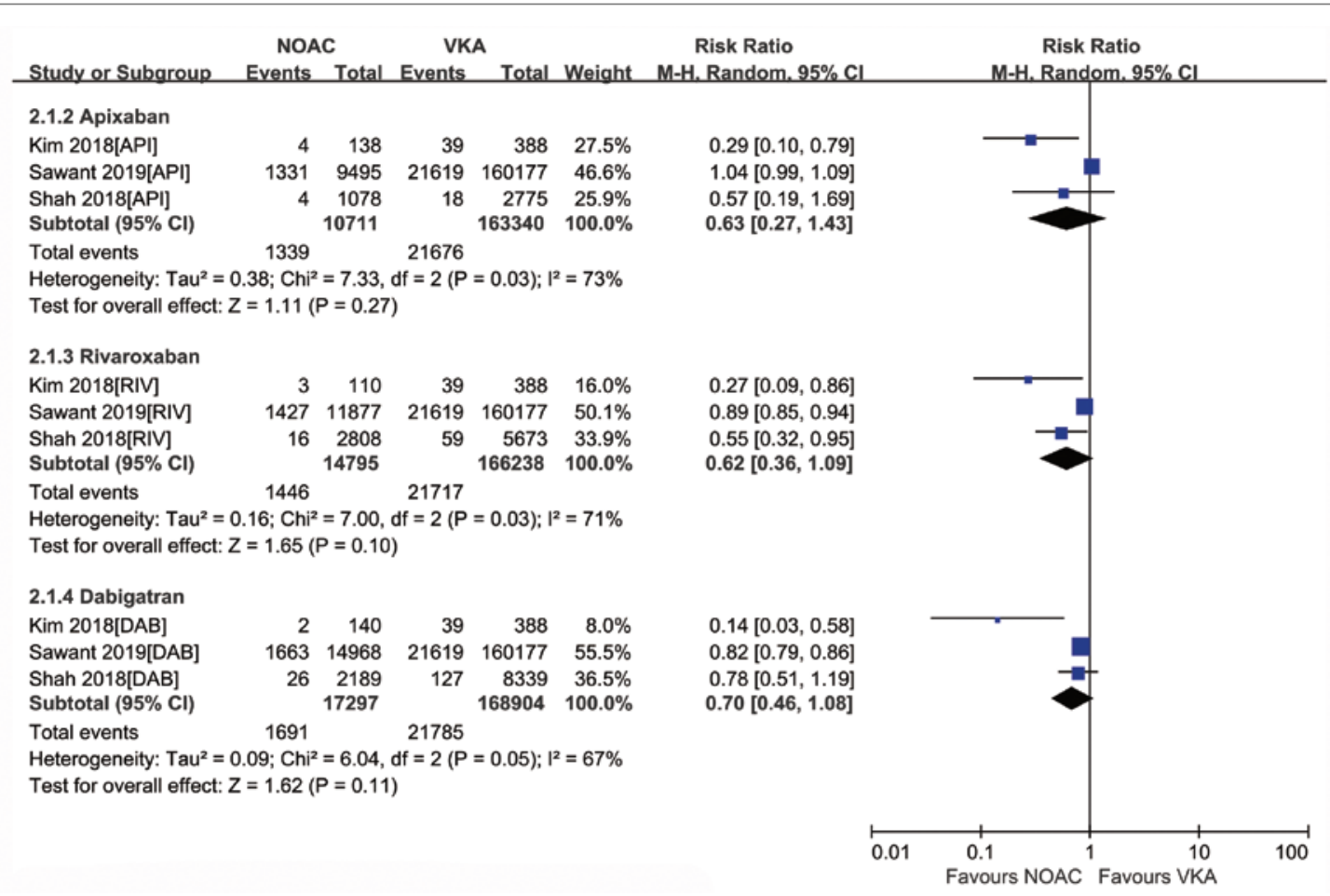

Figure S2: Forest plot comparing individual NOAC vs VKA regarding SSE in real-world patients with AF and cancer. Stroke or Systemic Embolism (SSE); Atrial Fibrillation (AF); Non-Vitamin K Antagonist Oral Anticoagulants (NOACs); Vitamin K Antagonists (VKAs); Apixaban (API); Rivaroxaban (RIV); Dabigatran (DAB) 


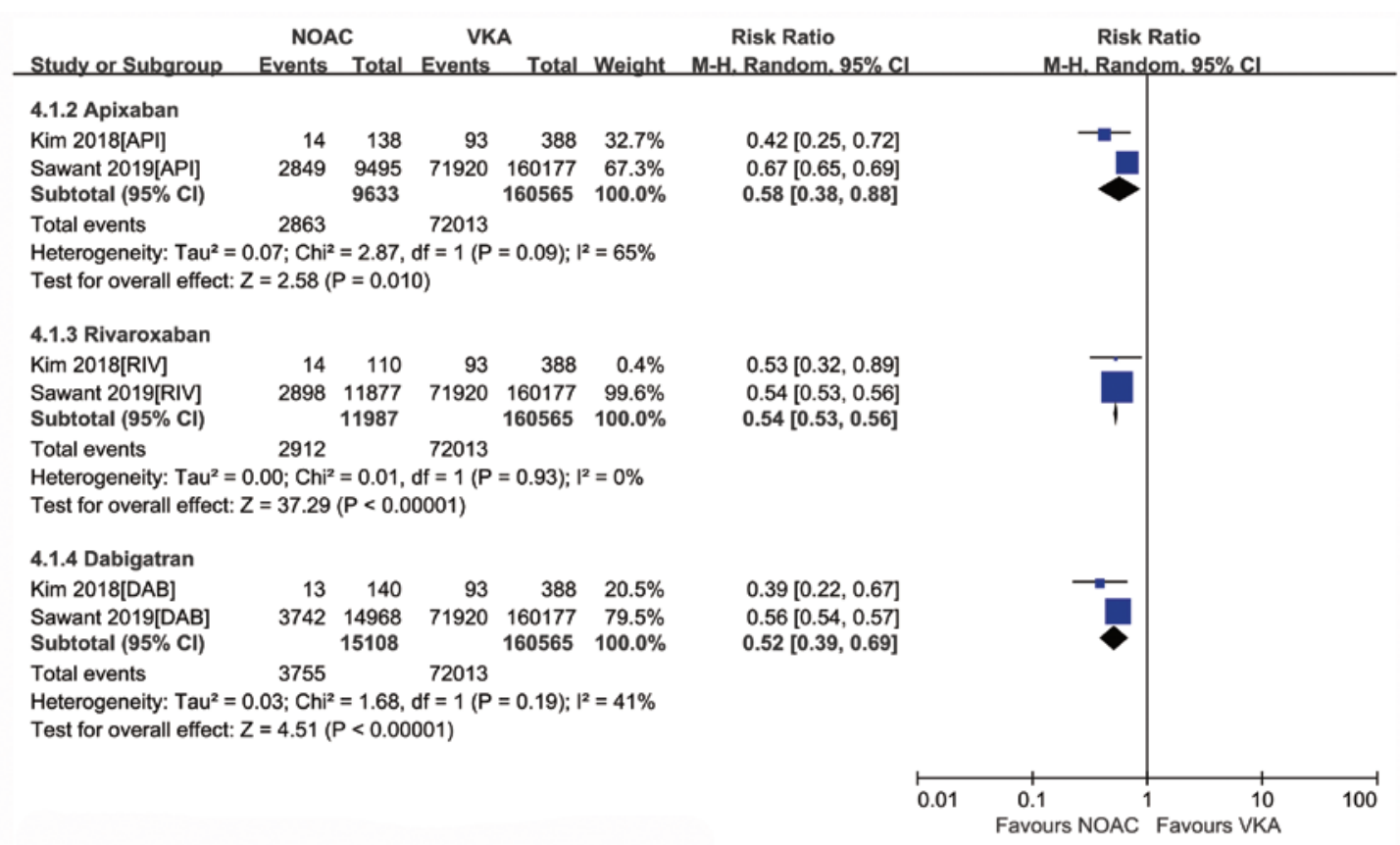

Figure S3: Forest plot comparing individual NOAC vs VKA regarding IS in real-world patients with AF and cancer. Ischaemic Stroke (IS); Atrial Fibrillation (AF); Non-Vitamin K Antagonist Oral Anticoagulants (NOACs); Vitamin K Antagonists (VKAs); Apixaban (API); Rivaroxaban (RIV); Dabigatran (DAB).

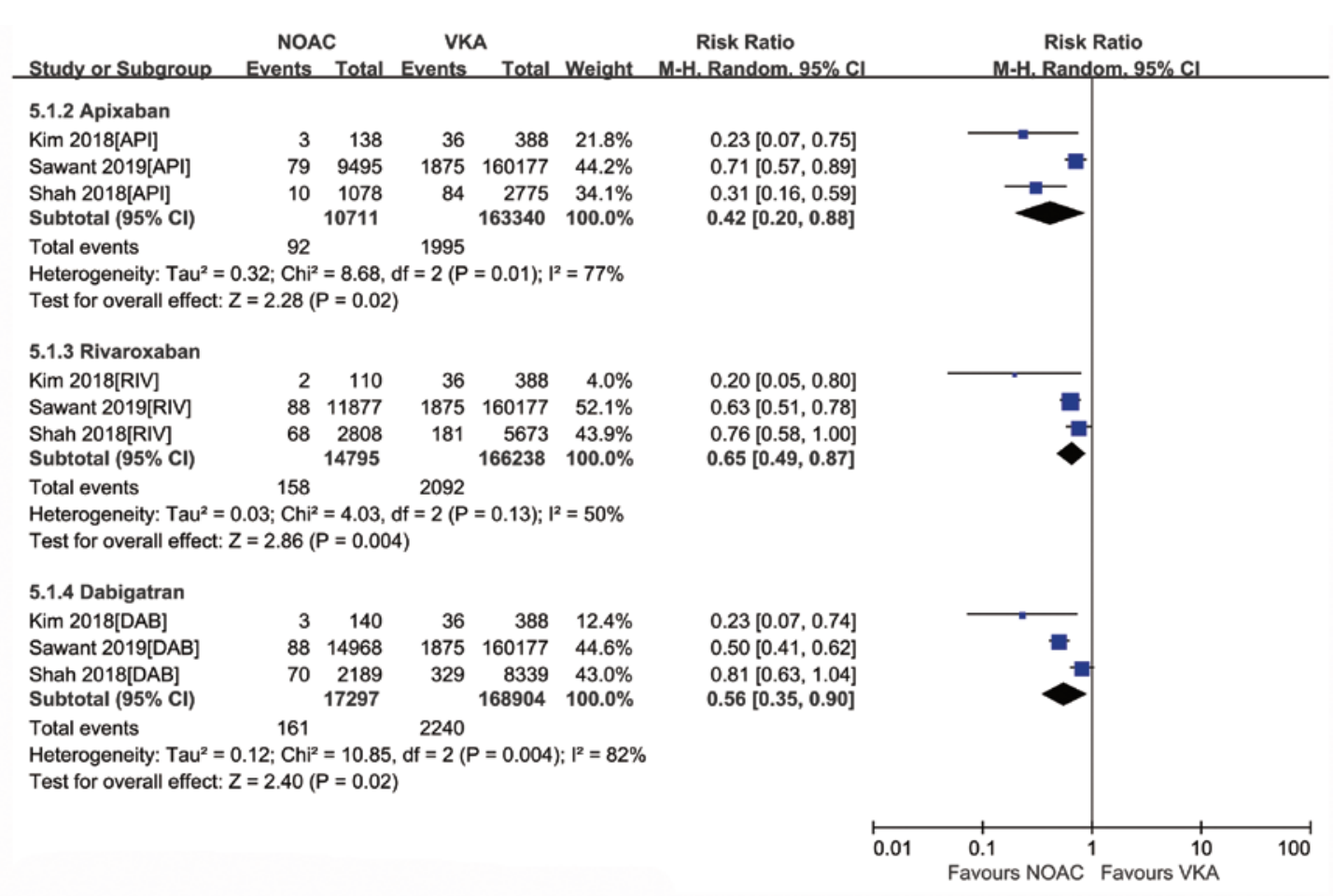

Figure S4: Forest plot comparing individual NOAC vs VKA regarding all-cause death in real-world patients with AF and cancer. Atrial Fibrillation (AF); Non-Vitamin K Antagonist Oral Anticoagulants (NOACs); Vitamin K Antagonists (VKAs); Apixaban (API); Rivaroxaban (RIV); Dabigatran (DAB). 


\begin{tabular}{|c|c|c|c|c|c|c|c|c|c|c|}
\hline Study or Subgroup & $\begin{array}{l}\text { NOA } \\
\text { Events }\end{array}$ & Total & $\begin{array}{l}\text { VK } \\
\text { Events }\end{array}$ & Total & Weight & $\begin{array}{l}\text { Risk Ratio } \\
\text { M-H. Random, } 95 \% \mathrm{Cl}\end{array}$ & & $\begin{array}{r}\text { Risk F } \\
\text { M-H. Rando }\end{array}$ & $\begin{array}{l}\text { Ratio } \\
\text { dom. } 95 \% \mathrm{Cl}\end{array}$ & \\
\hline \multicolumn{11}{|l|}{ 6.1.2 Apixaban } \\
\hline Kim 2018[API] & 3 & 138 & 33 & 388 & $21.2 \%$ & $0.26[0.08,0.82]$ & & & & \\
\hline Sawant 2019[API] & 79 & 9495 & 1875 & 160177 & $44.8 \%$ & $0.71[0.57,0.89]$ & & 둘 & & \\
\hline Shah 2018[API] & 10 & 1078 & 84 & 2775 & $34.0 \%$ & $0.31[0.16,0.59]$ & & & & \\
\hline Subtotal $(95 \% \mathrm{Cl})$ & & 10711 & & 163340 & $100.0 \%$ & $0.43[0.21,0.89]$ & & & & \\
\hline Total events & 92 & & 1992 & & & & & & & \\
\hline \multicolumn{11}{|c|}{$\begin{array}{l}\text { Heterogeneity: } \text { Tau }^{2}=0.29 ; \mathrm{Chi}^{2}=8.18, \mathrm{df}=2(\mathrm{P}=0.02) ; \mathrm{I}^{2}=76 \% \\
\text { Test for overall effect: } Z=2.28(P=0.02)\end{array}$} \\
\hline \multicolumn{11}{|l|}{ 6.1.3 Rivaroxaban } \\
\hline Kim 2018[RIV] & 2 & 110 & 33 & 388 & $3.5 \%$ & $0.21[0.05,0.88]$ & & & & \\
\hline Sawant 2019[RIV] & 88 & 11877 & 1875 & 160177 & $53.0 \%$ & $0.63[0.51,0.78]$ & & 불 & & \\
\hline Shah 2018[RIV] & 68 & 2808 & 181 & 5673 & $43.5 \%$ & $0.76[0.58,1.00]$ & & & & \\
\hline Subtotal $(95 \% \mathrm{Cl})$ & & 14795 & & 166238 & $100.0 \%$ & $0.66[0.50,0.86]$ & & & & \\
\hline Total events & 158 & & 2089 & & & & & & & \\
\hline \multicolumn{11}{|c|}{$\begin{array}{l}\text { Heterogeneity: } \text { Tau }^{2}=0.02 ; \mathrm{Chi}^{2}=3.61, \mathrm{df}=2(\mathrm{P}=0.16) ; \mathrm{I}^{2}=45 \% \\
\text { Test for overall effect: } Z=3.01(P=0.003)\end{array}$} \\
\hline \multicolumn{11}{|l|}{ 6.1.4 Dabigatran } \\
\hline Kim 2018[DAB] & 3 & 140 & 33 & 388 & $12.0 \%$ & $0.25[0.08,0.81]$ & & & & \\
\hline Sawant 2019[DAB] & 88 & 14968 & 1875 & 160177 & $44.9 \%$ & $0.50[0.41,0.62]$ & & 들 & & \\
\hline Shah 2018[DAB] & 70 & 2189 & 329 & 8339 & $43.2 \%$ & $0.81[0.63,1.04]$ & & & & \\
\hline Subtotal $(95 \% \mathrm{Cl})$ & & 17297 & & 168904 & $100.0 \%$ & $0.57[0.36,0.90]$ & & & & \\
\hline Total events & 161 & & 2237 & & & & & & & \\
\hline \multirow{2}{*}{\multicolumn{11}{|c|}{$\begin{array}{l}\text { Heterogeneity: } \mathrm{Tau}^{2}=0.11 ; \mathrm{Ch}^{2}=10.37, \mathrm{df}=2(P=0.006) ; \mathrm{I}^{2}=81 \% \\
\text { Test for overall effect: } Z=2.39(P=0.02)\end{array}$}} \\
\hline & & & & & & & & & & \\
\hline & & & & & & & 0.01 & 0.1 & 10 & 100 \\
\hline
\end{tabular}

Figure S5: Forest plot comparing individual NOAC vs VKA regarding major bleeding in real-world patients with AF and cancer. Atrial Fibrillation (AF); Non-Vitamin K Antagonist Oral Anticoagulants (NOACs); Vitamin K Antagonists (VKAs); Apixaban (API); Rivaroxaban (RIV); Dabigatran (DAB).

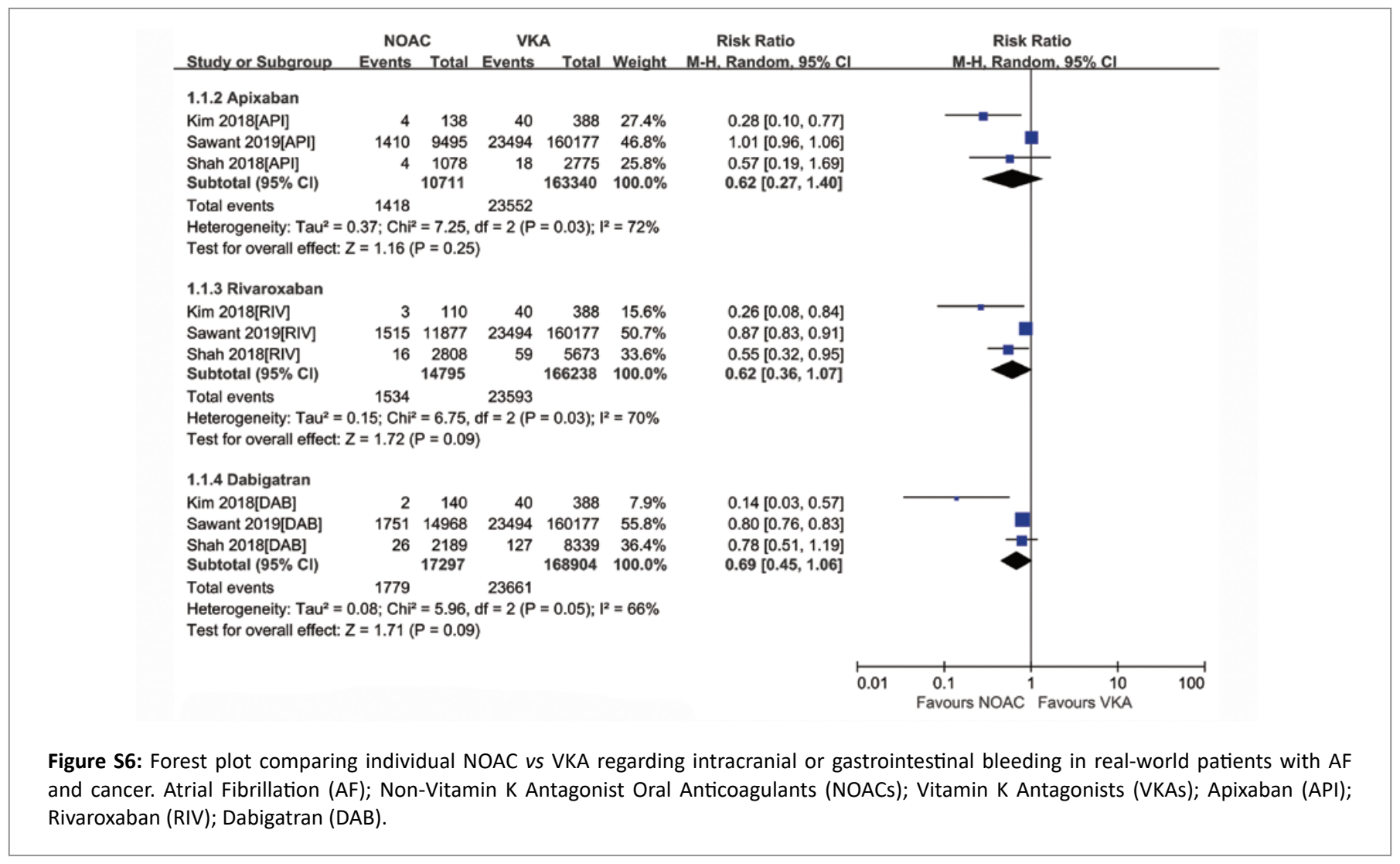

Citation: Cao B, Hu X, Chen M, Shen M, Xu L (2021) Efficacy and Safety of Non-Vitamin K Antagonist Oral Anticoagulants in Patients with Atrial Fibrillation and Cancer in Real-World: Meta-Analysis of Retrospective Observational Studies. J Drug Res Dev 7(1): dx.doi.org/10.16966/2470- 


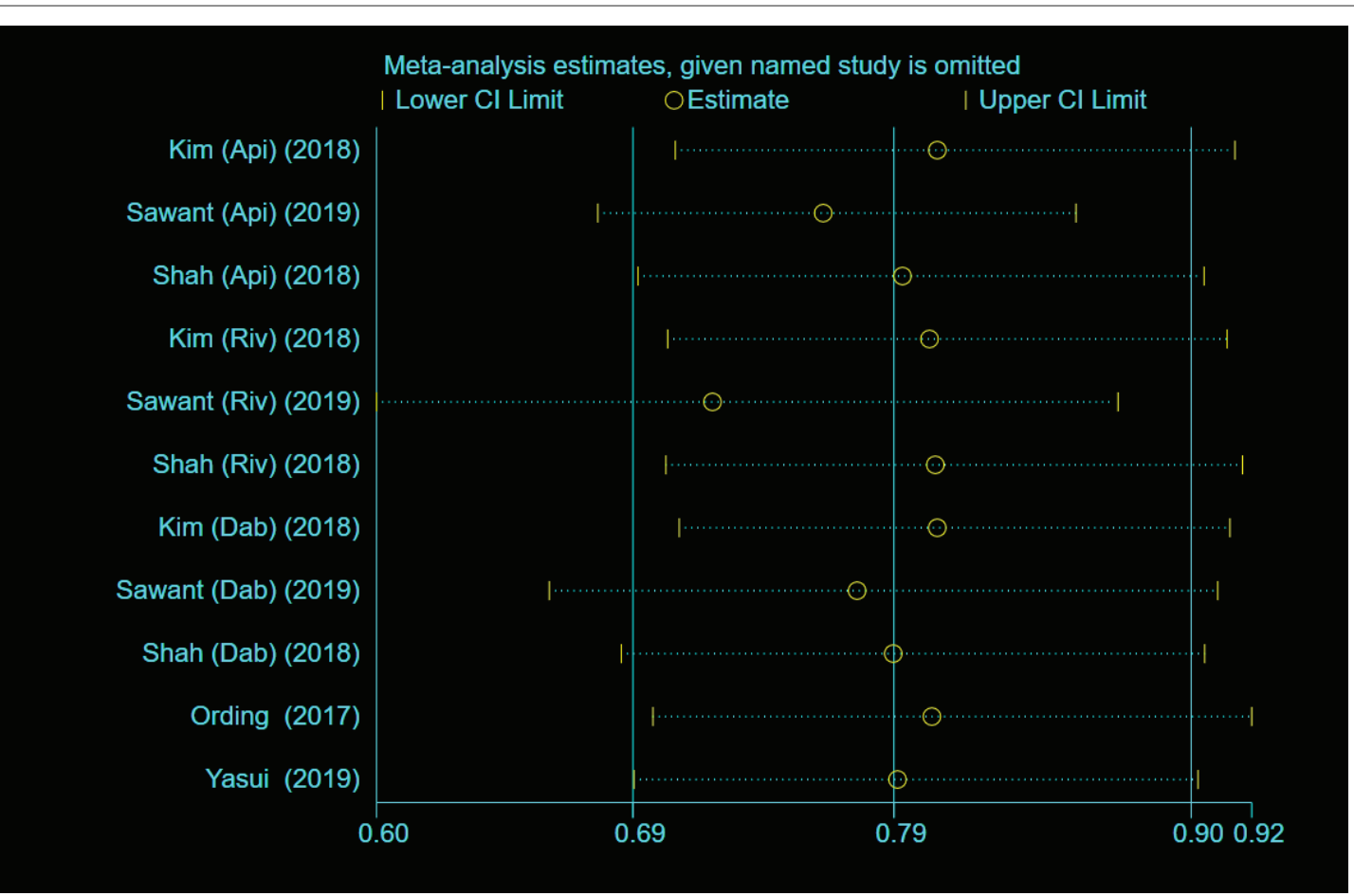

Figure S7: The leave-out-one sensitivity analysis results of the included studies. Apixaban (API); Rivaroxaban (RIV); Dabigatran (DAB). 